Article

\title{
Environmental Footprint of Cementitious Adhesives-Components of ETICS
}

\author{
Sebastian Czernik ${ }^{1}$, Marta Marcinek ${ }^{1}$, Bartosz Michałowski ${ }^{1}{ }^{\circledR}$, Michał Piasecki ${ }^{2}{ }^{\circledR}$, \\ Justyna Tomaszewska ${ }^{2}$ and Jacek Michalak ${ }^{1, *(D)}$ \\ 1 Research and Development Center, Atlas sp. z o.o., 2, Kilinskiego St., 91-421 Lodz, Poland; \\ sebastian.czernik@atlas.com.pl (S.C.); marta.marcinek@atlas.com.pl (M.M.); \\ bmichalowski@atlas.com.pl (B.M.) \\ 2 Building Research Institute, 1, Filtrowa St., 00-611 Warsaw, Poland; m.piasecki@itb.pl (M.P.); \\ j.tomaszewska@itb.pl (J.T.) \\ * Correspondence: jmichalak@atlas.com.pl
}

Received: 24 September 2020; Accepted: 23 October 2020; Published: 29 October 2020

\begin{abstract}
Energy saving is one of the strategic challenges facing our civilization today. Without decisive actions to reduce energy consumption, it is impossible to maintain the current standard of living. Energy consumption for heating and cooling purposes is one of the primary energy consumption sources in many countries. The external thermal insulation composite system (ETICS), which is today the most widely used solution in EU countries, increases buildings' energy efficiency. This article investigates the impact of producing cementitious adhesives, as part of ETICS with expanded polystyrene (EPS) or mineral wool (MW), on the natural environment using the cradle-to-gate life cycle assessment (LCA) method. Cementitious adhesives have a relatively low impact on most of the environmental indicators analyzed in the paper concerning other ETICS components. The paper aims to raise awareness of the importance of the environmental impact related to the production of cementitious adhesives. Knowledge of the construction products' environmental impact is fundamental for creating reliable databases, based on which, in the future, their environmental requirements will be determined. The environmental performance of building elements is essential for the correct determination of the buildings' sustainability.
\end{abstract}

Keywords: construction material; environmental impact; environmental product declaration (EPD); life cycle assessment (LCA); cementitious adhesives; external thermal insulation composite system (ETICS); global warming potential (GWP); sustainable building

\section{Introduction}

Climate change and environmental degradation pose a threat to the entire world. Since the Sithu U Thant report [1], which shook the world and made people aware of the danger, each year, the need to stop the rapidly progressing environmental degradation has been increasingly recognized. Since the 1980s, an essential role in shaping the way of thinking about mutual relations between society, economy, and natural environment resources has been played by the concept of sustainable development. It assumes that sustainable development is possible at the current level of civilization; i.e., one in which the needs of the present generation can be satisfied without diminishing the chances of future generations to meet them [2].

The European Union formulated a new growth strategy [3] in December 2019, intending to transform the Union into a modern, resource-efficient, and competitive economy. In line with this new strategy's assumptions, all EU countries will reach zero net greenhouse gas emissions by 2050, there will be a decoupling of economic growth from resource use, and no person or region of the Union will be left behind. 
The continually progressing devastation of the natural environment and excessive consumption of natural resources forces decision-makers to look for new solutions with the intention of minimizing restrictions on development, including, and perhaps most notably, in the area of construction. The construction industry consumes large amounts of natural resources, generating significant amounts of construction and demolition waste. European buildings are responsible for $36 \%$ of $\mathrm{CO}_{2}$ emissions and consume $40 \%$ of its energy [4]. An analysis of the housing stock of sixteen EU countries ( $66 \%$ of the building stock in the EU) showed that as much as $97 \%$ of the existing housing stock (building stock) must be modernized to achieve the neutrality goals of greenhouse gas emissions in 2050 [5]. On average, the annual deep renovation rate is only 0.4 to $1.2 \%$, depending on the country [6]. The most popular material in construction globally is concrete (globally, the most common material in buildings), including cement. The cement industry is responsible for $7 \%$ of greenhouse gas emissions globally [7]. All the figures mentioned above show that the construction sector will be pivotal in achieving the EU's energy and environmental goals. Better and more energy-efficient buildings improve residents' quality of life, bringing additional benefits to the economy and society.

The external thermal insulation composite system (ETICS), first used to insulate an apartment house in Germany in 1959, is currently the most popular and widely used building insulation technology in the European Union [8]. Sixty years of using ETICS has proved that this method is a stable and suitable solution $[9,10]$. It works well, even in Northern European countries where the ETICS is subjected to significant impacts of weather conditions-strong wind, frequent rainfall, hail, and snow [11]. It is also worth noting that the installation of the system is relatively quick from the consumer's perspective and takes place using relatively simple methods. The factors influencing a possible deterioration of the thermal insulation properties of ETICS are known. The most common ones are poor design, unsuitable construction materials, or construction technology inadequacies [12-14]. ETICS increases the energy efficiency of buildings and is used in both new and retrofitted buildings. ETICS manufacturers are continually developing their systems to meet customer expectations.

Insulating a building's external walls using ETICS means lower emissions of gases, especially $\mathrm{CO}_{2}$, to the atmosphere. It is essential to note that the ETICS is a kit defined in the Construction Products Regulation (CPR) [15], consisting of specific prefabricated elements applied directly to the facade at the construction site. ETICS, along with other construction products in the regulated European market, is subject to the CPR requirements, which means the assessment and verification of constancy of performance (AVCP). The CPR stipulates that it is necessary to consider building objects comprehensively with simultaneous consideration of all basic requirements: (1) mechanical resistance and stability, (2) safety in case of fire, (3) hygiene, health, and the environment, (4) safety and accessibility in use, (5) protection against noise, (6) energy economy and heat retention, and (7) sustainable use of natural resources

The first six basic requirements are commonly present in the AVCP of construction products before they are placed on the market. The seventh basic requirement concerning sustainable development is still absent from the applicable requirements. Thus, ETICS is not subject to a mandatory environmental impact assessment [16].

Following the CPR, the construction works must be designed, built, and demolished so that the use of natural resources is sustainable and, in particular, ensure the following:

- Reuse of recyclability of the construction works, their materials, and parts after demolition;

- The durability of the construction works;

- Use of environmentally compatible raw and secondary materials in the construction works.

According to the European Commission's policy, Environmental Product Declarations (EPD) can be considered an essential tool for implementing sustainable development principles. EPD is an independently verified and registered document that communicates transparent and comparable information about the life-cycle environmental impact of products. Due to their voluntary nature, however, they are not common. The number of EPDs issued increases year by year and amounted 
to over 7300 in January 2020 compared to 370 in August 2011. With, respectively, 1901 and 1363 EPDs issued, France and Germany are world leaders in this ranking. The Polish Building Research Institute (ITB) has released 105 EPDs [17]. In construction, nevertheless, these documents are still infrequently used. They are used in certification systems (also voluntarily) such as BREEAM, CASBEE, DGNB, HQE, LEED, ÖGNI, SBTool, and TQB, et al. [18-20]. To a much lesser extent, EPDs are used in business-to-business (B2B) communication [21]. The EPDs harmonized procedures for verification are of crucial importance for the proper placement of sustainable development issues in product assessment and CE marking. Without rationalizing the different approaches to EPD verification, the existing inconsistencies, or even errors in the data contained in the EPD, will not disappear [7,22-24].

Although the scientific literature on the environmental assessment of various products is extensive, not much has been published on the environmental impact of ETICS [25-37]. The environmental impact of such thermal insulation materials as mineral wool (MW), expanded polystyrene (EPS), extruded polystyrene (XPS), polyurethane (PUR), and glass wool (GW) is quite well known [38,39]. It is worth noting that the evolving concept of sustainable development is currently dominated by the view that, to achieve goals, it is necessary to integrate activities in each of three key dimensions; i.e., economic, environmental, and social $[40,41]$. In the Triple Bottom Line (TBL) concept, apart from the environmental impacts of ETICS, economic and social implications are also crucial [42-46].

This article focuses on presenting the environmental impact of cementitious mortars for bonding the thermal insulation material to the substrate of the external wall (adhesive for bonding) and cementitious mortars for embedding glass wool mesh (adhesive for a base coat), which are both elements of ETICS. The production of building materials consumes vast amounts of natural resources, generating significant amounts of waste, and it is crucial to know the resulting environmental consequences. Each publication presenting data on the environmental impact of building materials in the scientific literature also has another dimension-Sustainable Development Goals (SDGs) number 9, "Industry, innovation and infrastructure", and number 11, "Sustainable cities and communities", still have a small share among all seventeen UN defined SDGs [47].

\section{Materials and Methods}

\subsection{ETICS and Components: Cement-Based Adhesives}

The ETICS comprises a prefabricated insulation product (for example, in the form of polystyrene (EPS) or mineral wool (MW)) to be bonded onto an external wall. The insulation product is faced with a rendering system consisting of one or more layers (site applied), one of which contains reinforcing mesh. The rendering is applied directly to the insulation panels, without any air gap or disconnecting layer. The ETICS is applied to new or existing (modernized) vertical walls. The ETICS can also be used on horizontal or inclined surfaces that ensure proper drainage of rainwater and snow.

From the design point of view, ETICS are differentiated according to the methods of fixing: bonded ETICS, bonded ETICS with supplementary mechanical fixings, mechanically fixed ETICS with supplementary adhesive, and purely mechanically fixed ETICS.

As mentioned before, an ETICS manufacturer can only obtain a European Technical Assessment (ETA) developed on the requirements of ETAG 004 [16] guidelines to place the system on the market and CE mark it after AVCP of the ETICS. ETAG 004 specifies in great detail both the conditions for performing laboratory tests and the criteria for their verification and evaluation.

In some EU countries, as well as the EU system for marketing construction products with CE marking following the CPR requirements, there are national systems. In Poland, there is also a national system for introducing construction products with the B construction mark [48]. The idea of the operation of the national system is analogous to the EU system. In the case of ETICS, the basis for issuing the national assessment document is the fulfillment by the ETICS of the requirements included in the conditions of assessment of the performance of a construction product [49,50]. ETICS is assessed according to the Polish national assessment system's same basic requirements, using the same test 
methods as in the European legal requirements. Besides, due to national regulations, the fire spread rate and the vulnerability to algae growth can be assessed.

In this study, the environmental impact analysis was performed on cementitious mortars that are elements of two ETICS systems: Atlas ETICS with EPS [51] and Atlas ETICS Roker with MW [52]. In both systems, regardless of whether the thermal insulation material is an EPS or MW board, it can be bonded or bonded and mechanically fixed. In these systems, it is possible to use various adhesives, base coats, renders, and decorative coatings offered in multiple colors. For clarity of the paper, the environmental impact of cementitious mortars that are elements of ETICS was referred only to ETICS with mineral renders as the top layer of the system. All components of the ETICS used are listed in Table 1.

Table 1. Components of ETCIS with EPS or MW according to the National Technical Approvals ITB-AT-15 9090/2016 and ITB-AT-15-2930/2016.

\begin{tabular}{|c|c|c|c|}
\hline Component & Component Description & $\begin{array}{l}\text { Quantity } / \mathrm{m}^{2} \\
\text { ETICS with EPS }\end{array}$ & $\begin{array}{l}\text { Quantity/m } \mathrm{m}^{2} \\
\text { ETICS with MW }\end{array}$ \\
\hline $\begin{array}{l}\text { Adhesive } \\
\text { for bonding }\end{array}$ & Modified cementitious adhesives & $4.5 \mathrm{~kg}$ & $4.5-5.5 \mathrm{~kg}$ \\
\hline Insulation ${ }^{1}$ & Prefabricated EPS board or MW panel. ${ }^{2}$ & $\approx 1.35 \mathrm{~kg}$ & $3.5-4.5 \mathrm{~kg}$ \\
\hline $\begin{array}{l}\text { Adhesive } \\
\text { for base coat }\end{array}$ & Modified cementitious adhesives & $5.5 \mathrm{~kg}$ & $5.5-6.5 \mathrm{~kg}$ \\
\hline Glass fiber mesh ${ }^{1}$ & $\begin{array}{l}\text { Alkaline-resistant glass mesh with } \\
\text { nominal weight of } 150 \text { or } 165 \mathrm{~g} / \mathrm{cm}^{2} \text {. }\end{array}$ & $\geq 0.15 \mathrm{~kg}$ & $\geq 0.15 \mathrm{~kg}$ \\
\hline Key coat & $\begin{array}{l}\text { Dispersion-based key coat } \\
\text { with mineral/quartz fillers. }\end{array}$ & $\approx 0.2 \mathrm{~kg}$ & $\approx 0.3 \mathrm{~kg}$ \\
\hline Finishing coat & Modified cementitious render. & $2.0-4.5 \mathrm{~kg}$ & $2.0-4.5 \mathrm{~kg}$ \\
\hline Ancillary materials ${ }^{1}$ & Anchors, special fittings. & - & - \\
\hline
\end{tabular}

The arrangement of individual layers of ETICS is shown in Figure 1.

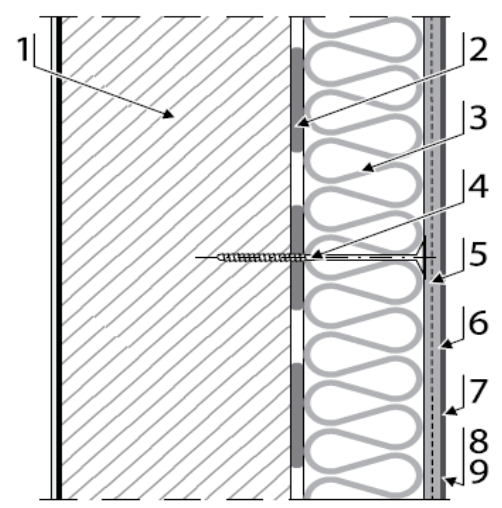

Figure 1. The arrangement of ETICS layers: (1) wall structure (substrate), (2) adhesive (basic fixing), (3) thermal insulation, (4) anchor (if necessary, additional fixing), (5) reinforcement layer (base coat with glass fiber mesh embedded), (6) key coating (if needed), (7) finishing coat (renders), (8) primers (optional), and (9) decorative coats (optional).

\subsection{Environmental Impact-Assessment Method}

The environmental impact of cementitious adhesives (adhesive for bonding and adhesive for a base coat) was assessed using the Life Cycle Assessment (LCA) method. The methods of impacts and aspects characterization were selected following the current models. The global warming total was calculated using the baseline model of 100 years developed by IPCC based on the IPCC 2013 protocol. The depletion of resources was calculated using the CML2002 approach. Photochemical ozone creation was determined using the LOTOS-EUROS model.

Type III EPD's for EPS-ETICS [53] and for MW-ETICS [54] released in March 2019 were prepared by following EN 15804 [55]. ITB experts verified the EPD's content according to ISO 14025 [56] requirements. 
The data used in the calculations related to 2017 production at five production facilities located in Poland: Bydgoszcz, Dąbrowa Górnicza, Piotrków Trybunalski, Suwałki, and Zgierz. The production volume of all ETICS components corresponded to approximately 10 million $\mathrm{m}^{2}$ of insulation of buildings' external walls, which correlates to about 45 thousand tons of cementitious mortars. In Poland, the ETICS market, estimated at around 40 million $\mathrm{m}^{2}$ yearly, is considered one of the biggest in Europe [8]. The production process of cementitious mortars (dry-mix mortars) is shown in Figure 2.

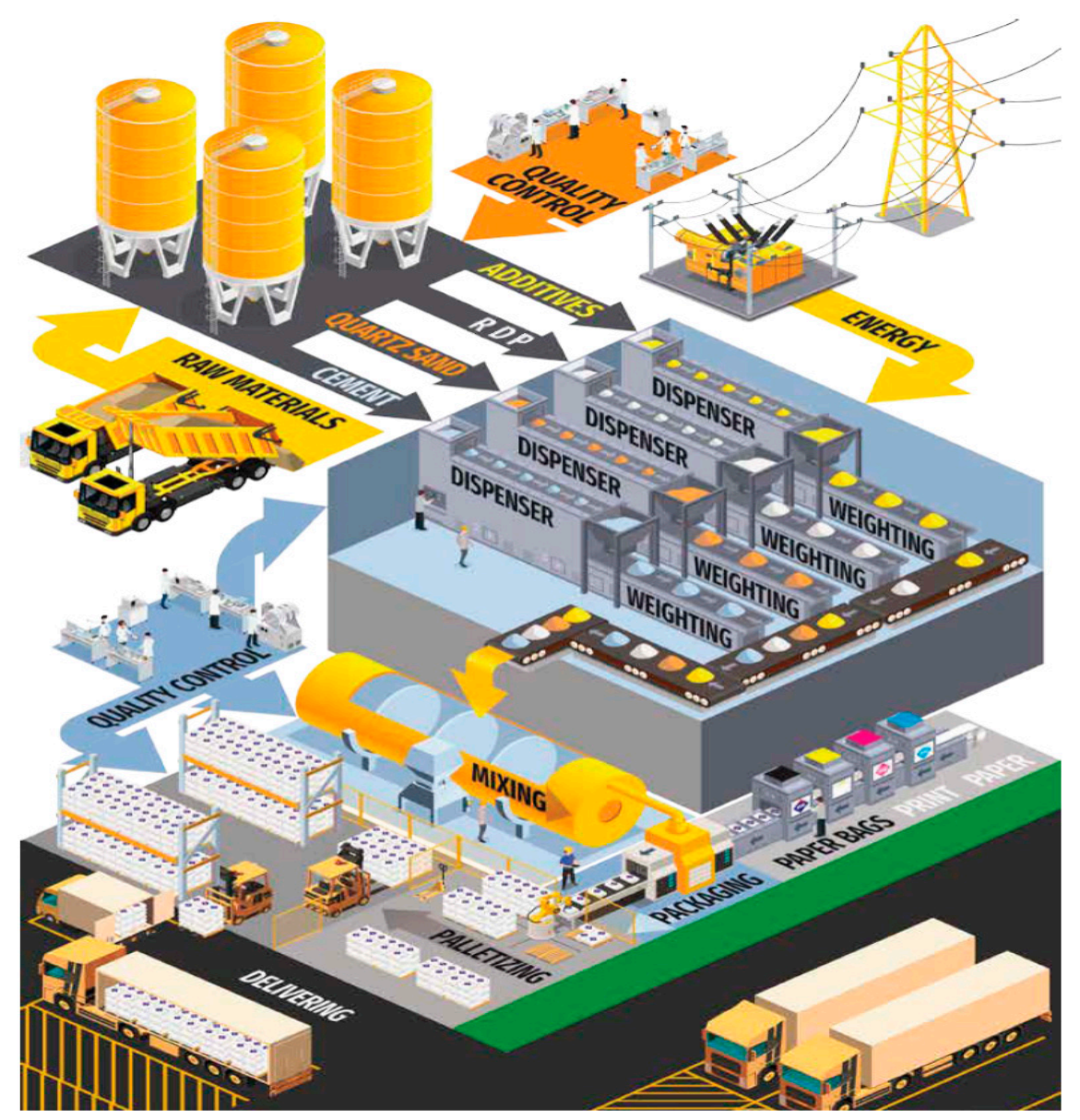

Figure 2. Scheme of the production process of cementitious mortars (dry-mix mortars). The abbreviation RDP in the figure means redispersible polymer powder.

The life cycle under study comprised modules A1 to A3. Module A1 refers to the extraction and processing of raw materials and the processing of secondary materials. Module A1 also includes recycling processes. A2 corresponds to the transport of the materials to the manufacturer and A3 to production processes. The total values of modules A1, A2, and A3 for studied cementitious adhesives have been analyzed in this paper.

The impacts and consumption of raw materials for each production plant and the entire production to representative products through mass allocation rules (i.e., the weighted average mass of given products) were assigned. Impacts at individual production locations were inventoried, set, and included in the calculations separately.

\section{Results}

Tables 2 and 3 show the environmental characteristics of cementitious adhesives, being components of the EPS-ETICS and MW-ETICS, calculated for $1 \mathrm{~kg}$, of:

- $\quad$ Global warming potential (GWP); 
- Depletion potential of the stratospheric ozone layer (ODP);

- Acidification potential of soil and water (AP);

- Eutrophication potential (EP);

- Formation potential of tropospheric ozone (POCP);

- Abiotic depletion potential (ADP-elements) for non-fossil resources;

- Abiotic depletion potential (ADP-fossil fuels) for fossil resources;

- Total use of renewable primary energy resources (primary energy and primary energy resources used as raw materials) (PERT);

- Total use of non-renewable primary energy resources (primary energy and primary energy resources used as raw materials) (PENRT).

Table 2. Summary of environmental indicators calculated for cementitious adhesives, components of the EPS-ETICS as described in National Technical Approval ITB-AT-15-9090/2016. Impacts were calculated based on the data from 2017.

\begin{tabular}{|c|c|c|c|c|c|}
\hline \multirow{2}{*}{ Indicator [unit] } & \multicolumn{5}{|c|}{ A1-A3 } \\
\hline & $\begin{array}{l}\text { Adhesive for } \\
\text { Bonding } \mathbf{A}^{1}\end{array}$ & $\begin{array}{l}\text { Adhesive for } \\
\text { Bonding B }{ }^{1}\end{array}$ & $\begin{array}{l}\text { Adhesive for } \\
\text { a Base Coat X }\end{array}$ & $\begin{array}{l}\text { Adhesive for } \\
\text { a Base Coat } Y^{2}\end{array}$ & $\begin{array}{c}\text { Adhesive for } \\
\text { a Base Coat } Z^{2}\end{array}$ \\
\hline \multicolumn{6}{|c|}{ Environmental impacts per $1 \mathrm{~kg}$ of product } \\
\hline GWP $[\mathrm{kg} \mathrm{CO} 2$ equations $]$ & $3.09 \times 10^{-1}$ & $3.34 \times 10^{-1}$ & $2.87 \times 10^{-1}$ & $3.32 \times 10^{-1}$ & $3.55 \times 10^{-1}$ \\
\hline ODP [kg CFC 11 equations] & $2.28 \times 10^{-6}$ & $6.76 \times 10^{-6}$ & $5.45 \times 10^{-6}$ & $8.03 \times 10^{-6}$ & $12.0 \times 10^{-6}$ \\
\hline $\mathrm{AP}\left[\mathrm{kg} \mathrm{SO} \mathrm{S}_{2}\right.$ equations $]$ & $8.70 \times 10^{-4}$ & $1.01 \times 10^{-3}$ & $9.10 \times 10^{-4}$ & $1.17 \times 10^{-3}$ & $1.33 \times 10^{-3}$ \\
\hline EP $\left[\mathrm{kg}\left(\mathrm{PO}_{4}\right)^{3-}\right.$ equations $]$ & $2.27 \times 10^{-4}$ & $1.74 \times 10^{-4}$ & $1.78 \times 10^{-4}$ & $2.15 \times 10^{-4}$ & $2.04 \times 10^{-4}$ \\
\hline POCP [kg Ethene equations $]$ & $6.57 \times 10^{-5}$ & $6.79 \times 10^{-5}$ & $6.89 \times 10^{-5}$ & $10.8 \times 10^{-5}$ & $9.00 \times 10^{-5}$ \\
\hline (ADP-elements) [kg Sb equations] & $1.67 \times 10^{-4}$ & $4.96 \times 10^{-4}$ & $4.77 \times 10^{-4}$ & $5.89 \times 10^{-4}$ & $8.77 \times 10^{-4}$ \\
\hline (ADP-fossil fuels) $[\mathrm{MJ}]$ & $8.23 \times 10^{-1}$ & $5.81 \times 10^{-1}$ & $7.39 \times 10^{-1}$ & $8.66 \times 10^{-1}$ & $6.85 \times 10^{-1}$ \\
\hline \multicolumn{6}{|c|}{ Environmental aspects related to the consumption of raw materials per $1 \mathrm{~kg}$ of product } \\
\hline PERT [MJ] & $4.66 \times 10^{-1}$ & $2.24 \times 10^{-1}$ & $4.54 \times 10^{-1}$ & $1.31 \times 10^{-1}$ & $4.54 \times 10^{-1}$ \\
\hline PENRT [MJ] & $6.68 \times 10^{-1}$ & $4.98 \times 10^{-1}$ & $6.69 \times 10^{-1}$ & $7.59 \times 10^{-1}$ & $5.76 \times 10^{-1}$ \\
\hline
\end{tabular}

Adhesives for bonding A, B, and adhesives for a base coat X, Y, and Z differ in the content of redispersible polymer powder. ${ }^{1}$ adhesive A contains less redispersible polymer powder than adhesive $B,{ }^{2}$ adhesive $X$ contains less redispersible polymer powder than $\mathrm{Y}$, which has less than $\mathrm{Z}$.

Table 3. Environmental characteristics of cementitious adhesives, components of the MW-ETICS as described in the National Technical Approval ITB-AT-15-2930/2016. Impacts were calculated based on data from 2017.

\begin{tabular}{|c|c|c|}
\hline \multirow{2}{*}{ Indicator [Unit] } & \multicolumn{2}{|c|}{ A1-A3 } \\
\hline & Adhesive for Bonding & Adhesive for Base Coat \\
\hline \multicolumn{3}{|c|}{ Environmental impacts per $1 \mathrm{~kg}$ of product } \\
\hline GWP [ $\mathrm{kg} \mathrm{CO}_{2}$ equations] & $3.57 \times 10^{-1}$ & $4.12 \times 10^{-1}$ \\
\hline ODP [kg CFC 11 equations] & $8.01 \times 10^{-6}$ & $1.00 \times 10^{-5}$ \\
\hline $\mathrm{AP}\left[\mathrm{kg} \mathrm{SO} \mathrm{S}_{2}\right.$ equations $]$ & $1.06 \times 10^{-3}$ & $1.28 \times 10^{-3}$ \\
\hline EP $\left[\mathrm{kg}\left(\mathrm{PO}_{4}\right)^{3-}\right.$ equations $]$ & $1.41 \times 10^{-4}$ & $1.96 \times 10^{-4}$ \\
\hline POCP [kg Ethene equations] & $8.38 \times 10^{-5}$ & $9.40 \times 10^{-5}$ \\
\hline (ADP-elements) [kg Sb equations] & $5.87 \times 10^{-4}$ & $7.37 \times 10^{-4}$ \\
\hline (ADP-fossil fuels) $[\mathrm{MJ}]$ & $5.73 \times 10^{-1}$ & $6.18 \times 10^{-1}$ \\
\hline \multicolumn{3}{|c|}{ Environmental aspects related to the consumption of raw materials per $1 \mathrm{~kg}$ of product } \\
\hline PERT $[\mathrm{MJ}]$ & $4.61 \times 10^{-1}$ & $4.74 \times 10^{-1}$ \\
\hline PENRT [MJ] & $5.69 \times 10^{-1}$ & $5.29 \times 10^{-1}$ \\
\hline
\end{tabular}

For the GWP, the A1 module's share in the sum of investigated modules was from $86.98 \%$ to $88.82 \%$ for cementitious adhesives, being components of EPS-ETICS. For the cementitious adhesives of the MW-ETICS, the A1 share was equal to $87.81 \%$ to $88.00 \%$. For EPS-ETICS, the module A2 of cementitious adhesives (transport to the manufacturer) varied from $1.96 \%$ to $2.67 \%$. For MW-ETICS, the A2 module of cementitious adhesives was from $1.01 \%$ to $2.23 \%$. The share of module A3 (production of cementitious adhesives) ranged from $9.22 \%$ to $11.44 \%$ for EPS-ETICS and from $9.77 \%$ to $11.19 \%$ for 
MW-ETICS. For most of the analyzed environmental indicators of cementitious adhesives, the share of module A1 is dominant in the three considered modules.

Cementitious adhesives represent a significant mass fraction of the total ETICS. According to Albrecht et al., dealing with ETICS recycling issues, adhesive mortars' mass share in the installed ETICS is 36\% [57]. For this reason, when we consider the environmental impact of all ETICS components, the percentage of the A2 module (transport) for the GWP index is much lower; i.e., from $0.17 \%$ to $0.38 \%$ for EPS-ETICS with $10 \mathrm{~cm}$ and $25 \mathrm{~cm}$ thick insulation material [35] than for cementitious mortars itself.

As mentioned earlier, ETICS is set, in the meaning of the CPR, and consists of specific prefabricated elements that are applied directly to the facade at the construction site. The AVCP of the ETICS, both in the EU system (CPR) and in the Polish national system, are carried out for the entire system, not for individual elements. Thus, it is worth presenting the determination of the share of cementitious adhesives on the values of different indicators of environmental impacts.

Figure 3 shows the environmental impact of cementitious mortars broken down into adhesives for bonding insulation and adhesives for a base coat and the rest of the remaining components of ETICS with EPS and MW for two thicknesses of the thermal insulation material, $10 \mathrm{~cm}$ and $25 \mathrm{~cm}$. EPS and MW have a significant impact on the studied environmental indicators' value, as shown in Figure 3 and described earlier.

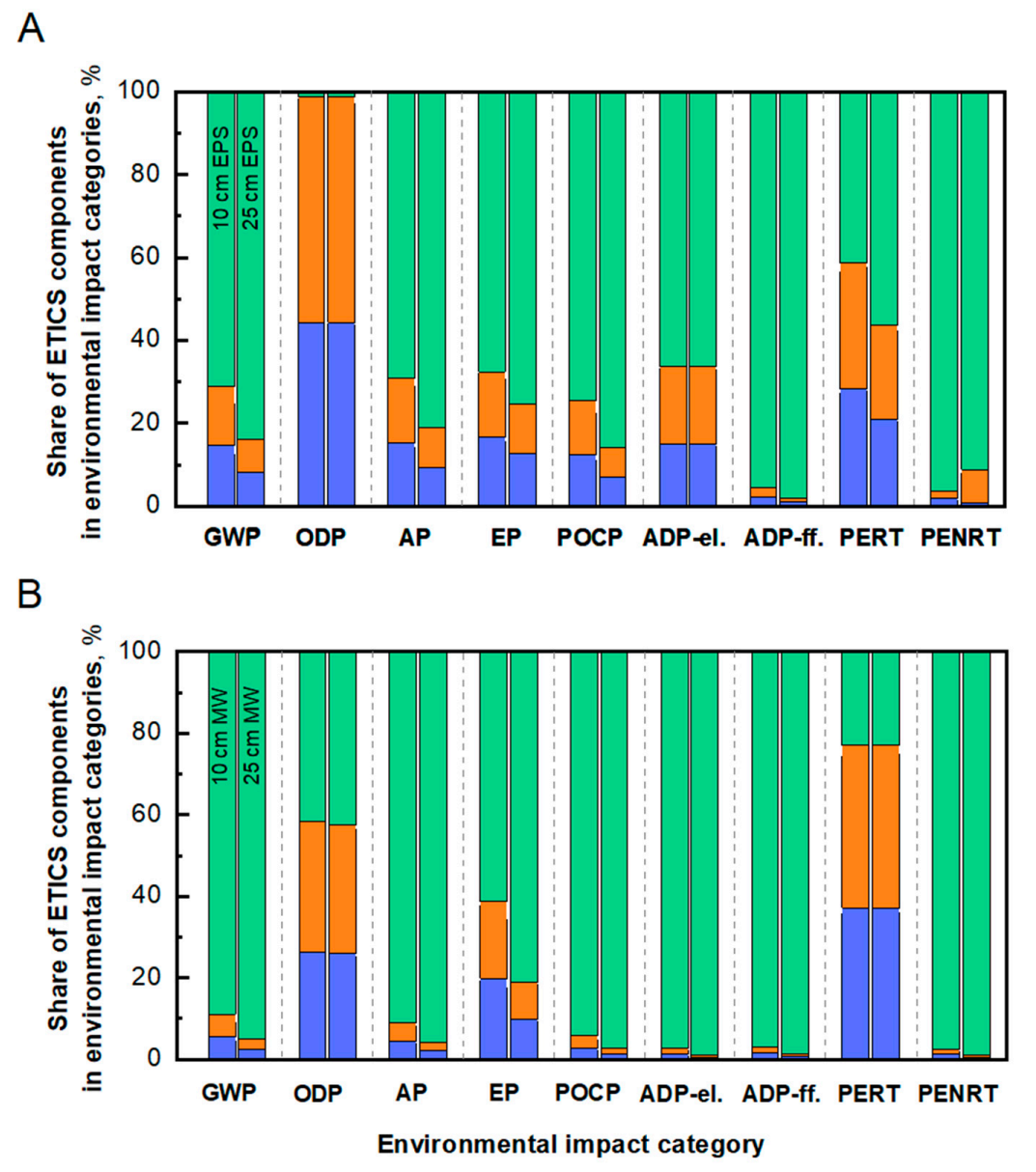

Figure 3. The share of environmental impacts of cementitious adhesives and the rest of the ETICS in the system (A1-A3 modules). Legend: (A) for ETICS produced according to the National Technical Approval ITB-AT-15-9090/2016 for $10 \mathrm{~cm}$ and $25 \mathrm{~cm}$ thickness of the EPS board, (B) for ETICS produced according to the National Technical Approval ITB-AT-15-2930/2020 for $10 \mathrm{~cm}$ and $25 \mathrm{~cm}$ thickness of the MW board, ( $\square$ ) adhesive for bonding insulation, $(\square)$ adhesive for a base coat, ( $\square$ ) sum of the other components (insulation material, glass fiber mesh, key coat, and finishing coat). 


\section{Discussion}

To better illustrate the ETICS market's dimension and its impact on the environment, it is worth quoting a few numbers. In 2017, $\mathrm{CO}_{2}$ emissions from the heating/cooling activities of households in Poland amounted to 35.7 million tons [58]. The total emissions of $\mathrm{CO}_{2}$ and greenhouse gas GHG in Poland in 2017 were equivalent to 319.0 million tons of $\mathrm{CO}_{2}$ [59] and 413.8 million tons of $\mathrm{CO}_{2}$ equivalent, excluding Land Use, Land Use Change, and Forestry (LULUCF) [60], respectively. The data analyzed come from the same year, 2017, as shown above. Table 4 presents the GWP of manufacturing ETICS (modules A1-A3), with the assumption that, in 2017, about 40 million $\mathrm{m}^{2}$ of external walls were insulated in Poland [35]. Because the subject of the work is, above all, the analysis of the environmental impact of cementitious adhesives, it is worth noting that the GWP for 1 ton of the Portland cement CEM I produced under EN 197-1 [61] in 2017 in Poland amounted to $0.889 \mathrm{tCO}_{2}$ equations, while in the EU countries it was $0.898 \mathrm{t} \mathrm{CO}_{2}$ equations [62].

Table 4. Global warming potential of manufacturing ETICS (modules A1-A3) calculated for 40 million $\mathrm{m}^{2}$ insulated external walls annually with ETICS with MW $(10 \mathrm{~cm}$ and $25 \mathrm{~cm})$ and with EPS $(10 \mathrm{~cm}$ and $25 \mathrm{~cm})[35]$.

\begin{tabular}{ccc}
\hline \multirow{2}{*}{$\begin{array}{c}\text { Insulation Material Thickness } \\
\text { in ETICS [cm] }\end{array}$} & \multicolumn{2}{c}{ GWP [t $\mathbf{C O}_{2}$ Equations] } \\
\cline { 2 - 3 } & EPS & MW \\
\hline 10 & 348,000 & $1,060,000$ \\
25 & 628,000 & $2,348,000$ \\
\hline
\end{tabular}

For ETICS with EPS, data for two cementitious adhesives for bonding insulation and three cementitious adhesives for a base coat are presented. These products meet the requirements set out in ITB-AT-15-9090/2016; i.e., the document constituting the basis for AVCP. As mentioned earlier, outcomes related to the seventh basic requirement-sustainable development-are not assessed. So far, there are no requirements in this regard. Analyzing the GWP values for adhesives for bonding between mortar A and mortar B, the data show that mortar A has a GWP value that is lower by $7.4 \%$ than mortar B. The difference between adhesives for base coat $\mathrm{Z}$ and the analogous mortar $\mathrm{X}$ is much higher; i.e., $19.2 \%$. The differences between adhesives for bonding insulation (mortar $\mathrm{A}$ and mortar $B$ are intended for the same applications) and in the adhesives for a base coat group (mortars $\mathrm{X}, \mathrm{Y}$, and $\mathrm{Z}$ are intended for similar applications) also occur for the other environmental indicators analyzed in this study: ODP, AP, EP, POCP, ADP-elements, ADP-fossil fuels, PERT, and PENRT. Nowadays, when formulating cementitious adhesives, their designers consider the necessity to meet technical requirements that guarantee the possibility of obtaining a positive assessment and verification of functional properties and the economic factor. At the stage of designing construction products, environmental requirements are either not taken into account or are only considered to a minimal extent.

The cementitious adhesives used in ETICS with MW have a higher GWP value than their equivalents used in ETICS with EPS. The raw materials used for the production of cementitious adhesives that have the most significant impact on environmental indicators' values are cement and redispersible polymeric powders (RDP). Other ingredients (raw materials), such as quartz and dolomite fillers, methylcellulose ethers, wetting agents, and setting time regulators, have a relatively lesser effect on the values of environmental indicators. Cementitious adhesives have a relatively low impact on most of the environmental indicators analyzed in this paper, except for ODP and PERT, when compared to other ETICS components. Publication of data on the environmental impact of cement mortars that are components of ETICS is also essential in the aspect of collecting data that can be used in the future when setting requirements for the broadly understood sustainable development of construction products. According to Anderson and Moncaster [7], who analyzed all available EPDs for cementitious materials, aggregates, admixture, and ready-mix concrete products in August 2019, 
of the 118 EPDs identified and analyzed, 102 relate to cement products. The authors also point out many inconsistencies or even errors in the EPD, the causes of which they examine. Referring to the analysis results by Anderson and Moncaster [7], and similar conclusions have been drawn by other scientists [22-24], it is necessary to collect and analyze data on the environmental impact of products. There is a need to build reliable databases on the environmental impact of construction products and continuously monitor changes in this area. The study published just recently by Palumbo et al. shows that, currently, the use of EPD in building information modeling (BIM) is not directly feasible. It requires prior appropriate preparation of information on environmental indicators [63].

Publication of data on the environmental impact of cement mortars or ETICS that are construction products should be considered as innovations in construction. In a modern building, it is necessary to determine the negative environmental impact of construction products. The knowledge of the negative effects of construction products is the only way to solve the existing problems. Activities aimed at reducing the negative impact of construction products on the environment should be treated as an innovation in construction $[64,65]$.

\section{Conclusions}

There is no doubt that today there is a need to develop a clearer understanding of the environmental impact in the case of construction products and how it relates to other basic requirements. This article provides data for nine environmental indicators (GWP, ODP, AP, EP, POCP, ADP-elements, ADP-fossil fuels, PERT, and PERNT) of cementitious adhesives, thus contributing to the process of better understanding the environmental dimension of construction products. Cementitious adhesives have a relatively low impact on most of the environmental indicators analyzed in this paper, except for ODP and PERT, compared to other ETICS components. To achieve more sustainable production and consumption patterns, we have to know and consider the environmental implications of the products' whole supply-chain. For most of the analyzed environmental indicators of cementitious adhesives, the share of module A1 is dominant in three modules, A1-A3. The adhesives for bonding insulation and adhesives for a base coat analyzed in this paper are characterized by a relatively low share of the values of the individual environmental indicators of the entire ETICS.

Sustainability assessment and sustainability indicators should be powerful decision-supporting tools that foster sustainable development, not only in the construction sector. For the reasons mentioned above, as much data as possible on construction products' environmental impact must be widely available. In this sense, EPD's, scientific articles, and different initiatives to benchmark obtained results are needed. EPD's and scientific articles are a possible solution that will help to compare the environmental performance of construction products (any products) with those of a company's competitors. Each EPD or scientific article is facilitating communication.

In line with the European Commission's announcements and the CPR requirements in a few years, the environmental impact may be part of the mandatory AVCP of building materials.

Author Contributions: Conceptualization: J.M.; formal analysis: S.C., M.M., M.P., and J.T.; investigation: B.M., M.M., J.T., and J.M.; methodology: S.C., B.M., M.P., J.T., and J.M.; project administration: J.M.; resources: S.C., M.M., and J.T.; supervision: J.M.; validation: M.P. and J.T.; visualization, B.M.; writing一original draft preparation: J.M.; writing-review and editing, J.M. and B.M. All authors have read and agreed to the published version of the manuscript.

Funding: B.M. and M.M. were partially supported by the Regional Operational Program for Łódzkie Voivodeship 2014-2020 (Project number RPLD.01.02.02-10-014/19-00), and J.M. was partially supported by the Smart Growth Operational Program 2014-2020 (Project number POIR.02.01.00-00-0350/16).

Conflicts of Interest: The authors declare no conflict of interest.

\section{References}

1. Thant, U. Problems of the Human Environment; Report of the Secretary-General; United Nations Economic and Social Council: New York, NY, USA, 1969. 
2. Brundtland, G.H. Report of the World Commission on Environment and Development: Our Common Future. 1987. Available online: http://www.un-documents.net/our-common-future.pdf (accessed on 26 July 2020).

3. European Commission. The European Green Deal; European Commission: Brussels, Belgium, 2019.

4. European Commission. Energy Performance of Buildings Directive. Available online: https://ec.europa.eu/ energy/topics/energy-efficiency/energy-efficient-buildings/energy-performance-buildings-directive_en (accessed on 26 July 2020).

5. Building Performance Institute Europe, Brussels, Belgium. 2020. Available online: http://bpie.eu/wp-content/ uploads/2017/12/State-of-the-building-stock-briefing_Dic6.pdf (accessed on 26 July 2020).

6. Esser, A.; Dunne, A.; Meeusen, T.; Quaschning, S.; Wegge, D.; Hermelink, A.; Schimschar, S.; Offermann, M.; John, A.; Reiser, M.; et al. Comprehensive Study of Building Energy Renovation Activities and the Uptake of Nearly Zero-Energy Buildings in the EU. Final Report; European Commission: Brussels, Belgium, 2019. Available online: https:/ec.europa.eu/energy/sites/ener/files/documents/1.final_report.pdf (accessed on 27 July 2020).

7. Anderson, J.; Moncaster, A. Embodied carbon of concrete in buildings, Part 1: Analysis of published EPD. Build. Cities 2020, 1, 198-217. [CrossRef]

8. Pasker, R. The European ETICS market-Do ETICS sufficiently contribute to meet political objectives? In Proceedings of the 4th European ETICS Forum, Warsaw, Poland, 5 October 2017; European Association for External Thermal Insulation Composite Systems (EAE): Baden-Baden, Germany, 2017.

9. Künzel, H.; Künzel, H.M.; Sedlbauer, K. Long-term performance of external thermal insulation systems (ETICS). Acta Archit. 2006, 5, 11-24.

10. Kienzlen, V.; Erhorn, H.; Krapmeier, H.; Lutzkendorf, T.; Werner, J.; Wagner, A. The Significance of Thermal Insulation Arguments Aimed at Overcoming Misunderstandings, 3rd ed.; Fraunhofer-Publica: Karlsruhe, Germany, 2014; p. 35.

11. Kvande, T.; Bakken, N.; Bergheim, E.; Thue, J.V. Durability of ETICS with rendering in Norway-Experimental and field investigations. Buildings 2018, 8, 93. [CrossRef]

12. Lembo, F.; Marino, F.P.R. The pathologies of the ETICS. In Recent Developments in Building Diagnosis Techniques; Springer: Singapore, 2016; pp. 37-49.

13. Sulakatko, V.; Lill, I.; Witt, E. Methodological framework to assess the significance of External Thermal Insulation Composite System (ETICS) on-site activities. Energy Procedia 2016, 96, 446-454. [CrossRef]

14. Sulakatko, V.; Liisma, E.; Soekov, E. Increasing construction quality of external thermal insulation composite system (ETICS) by revealing on-site degradation factors. Procedia Environ. Sci. 2017, 38, 765-772. [CrossRef]

15. Regulation (EU) No 305/2011 of the European Parliament and of the Council. Available online: https://eur-lex.europa.eu/legal-content/EN/TXT/?uri=uriserv:OJ.L_.2011.088.01.0005.01.ENG\&toc= OJ:L:2011:088:TOC (accessed on 26 July 2020).

16. European Organization for Technical Assessment (EOTA). ETAG 004: Guideline for European Technical Approval of External Thermal Insulation Composite Systems (ETICS) with Rendering; European Organization for Technical Assessment (EOTA): Brussels, Belgium, 2013.

17. Anderson, J. Construction LCA's 2020 Guide to Environmental Product Declarations. Available online: https://infogram.com/constructionlcas-2020-guide-to-epd-1h7g6kgqx9zo4oy?live (accessed on 23 July 2020).

18. Gelowitz, M.D.C.; McArthur, J.J. Investigating the effect of environmental product declaration adoption in LEED $^{\circledR}$ on the construction industry: A case study. Procedia Eng. 2016, 145, 58-65. [CrossRef]

19. Andersen, S.C.; Larsen, H.F.; Raffnsøe, L.; Melvang, C. Environmental product declarations (EPDs) as a competitive parameter within sustainable buildings and building materials. IOP Conf. Ser. Earth Environ. Sci. 2019, 323, 012145. [CrossRef]

20. Bitsiou, E.; Giarma, C. Parameters related to building components' life-cycle analysis in methods for buildings' environmental performance assessment. IOP Conf. Ser. Earth Environ. Sci. 2020, 410, 012066. [CrossRef]

21. Galindro, B.M.; Welling, S.; Bey, N.; Olsen, S.I.; Soares, S.R.; Ryding, S.-O. Making use of life cycle assessment and environmental product declarations. A survey with practitioners. J. Ind. Ecol. 2020, 24, 1-11. [CrossRef]

22. Passer, A.; Kreiner, H.; Maydl, P. Assessment of the environmental performance of buildings: A critical evaluation of the influence of technical building equipment on residential buildings. Int. J. Life Cycle Assess. 2012, 17, 1116-1130. [CrossRef] 
23. Passer, A.; Lasvaux, S.; Allacker, K.; De Lathauwer, D.; Spirinckx, C.; Wittstock, B.; Kellenberger, D.; Gschösser, F.; Wall, J.; Wallbaum, H. Environmental product declarations entering the building sector: Critical reflections based on 5 to 10 years' experience in different European countries. Int. J. Life Cycle Assess. 2015, 20, 1199-1212. [CrossRef]

24. Božiček, D.; Kunič, R.; Košir, M. Interpreting environmental impacts in building design: Application of a comparative assertion method in the context of the EPD scheme for building products. J. Clean. Prod. 2020, 279, 123399. [CrossRef]

25. Bisegna, F.; Mattoni, B.; Gori, P.; Asdrubali, F.; Guattari, C.; Evangelisti, L.; Sambuco, S.; Bianchi, F. Influence of insulating materials on green building rating system results. Energies 2016, 9, 712. [CrossRef]

26. Potrč, T.; Malovrh Rebec, K.; Kneza, F.; Kuničb, R.; Legata, A. Environmental footprint of external thermal insulation composite systems with different insulation types. Energy Procedia 2016, 96, 312-322. [CrossRef]

27. Dylewski, R.; Adamczyk, J. Study on ecological cost-effectiveness for the thermal insulation of building external vertical walls in Poland. J. Clean. Prod. 2016, 133, 467-478. [CrossRef]

28. Sierra-Pérez, J.; Boschmonart-Rives, J.; Gabarrell, X. Environmental assessment of façade-building systems and thermal insulation materials for different climatic conditions. J. Clean. Prod. 2016, 113, 102-113. [CrossRef]

29. Minarovičová, K.; Dlhý, D. Environmentally safe system for treatment of biocorrosion of ETICS. MATEC Web Conf. 2018, 146, 03005. [CrossRef]

30. Sattler, S.; Österreicher, D. Assessment of sustainable construction measures in building refurbishment-life cycle comparison of conventional and Multi-Active Façade systems in a social housing complex. Sustainability 2019, 11, 4487. [CrossRef]

31. Silvestre, J.D.; Castelo, A.M.P.; Silva, J.J.B.C.; Brito, J.M.C.L.; Pinheiro, M.D. Retrofitting a building's envelope: Sustainability performance of ETICS with ICB or EPS. Appl. Sci. 2019, 9, 1285. [CrossRef]

32. Michałowski, B.; Marcinek, M.; Tomaszewska, J.; Czernik, S.; Piasecki, M.; Geryło, R.; Michalak, J. Charakterystyka środowiskowa systemów ETICS w latach 2014-2019 (Environmental characteristics of the ETICS systems between 2014 and 2019). Mater. Bud. 2019, 12, 22-25.

33. Michałowski, B.; Marcinek, M.; Tomaszewska, J.; Czernik, S.; Piasecki, M.; Geryło, R.; Michalak, J. Influence of rendering type on the environmental characteristics of expanded polystyrene-based external thermal insulation composite system. Buildings 2020, 10, 47. [CrossRef]

34. Librelotto, L.I.; Kekez, M.; Bártolo, H.M.G. The environmental impact of ETICS layer: A case of study with life cycle assessment (LCA) from environmental product declaration (EPD) in Portugal. MIX Sustentável 2020, 6, 139-148.

35. Michalak, J.; Czernik, S.; Marcinek, M.; Michałowski, B. Environmental burdens of external thermal insulation systems. expanded polystyrene vs. mineral wool: Case study from Poland. Sustainability 2020, 12, 4532. [CrossRef]

36. Kraus, M.; Žáková, K.; Žák, J. Economic-environmental and technological assessment of ETICS. EasyChair 2020, 3425.

37. Matos, M.; Soares, L.; Silva, L.; Sequeira, P.; Carvalho, J. Life cycle assessment of an ETICS system composed of a natural insulation material: A case study of a system using an insulation cork board (ICB). In Portugal SB13 Contribution of Sustainable Building to Meet EU 20-20-20 Targets; Multicomp-Artes Gráficas, Lda: Guimarães, Portugal, 2013; Chapter 11; pp. 855-862. Available online: https://www.irbnet.de/daten/iconda/CIB_DC26483. pdf (accessed on 26 July 2020).

38. Sierra-Pérez, J.; Boschmonart-Rives, J.; Gabarrell, X. Comparative Combinations of Façade-Building Systems and Thermal Insulation Materials for Different Climatic Conditions: An Environmental Assessment. Available online: https://pdfs.semanticscholar.org/89ba/d242f4b3480f363bd3851590bd433746d556.pdf (accessed on 26 July 2020).

39. Braulio-Gonzalo, M.; Bovea, M.D. Environmental and cost performance of building's envelope insulation materials to reduce energy demand: Thickness optimization. Energy Build. 2017, 150, 527-545. [CrossRef]

40. Akadiri, P.O.; Chinyio, E.A.; Olomolaiye, P.O. Design of a sustainable building: A conceptual framework for implementing sustainability in the building sector. Buildings 2012, 2, 126-152. [CrossRef]

41. Alhaddi, H. Triple bottom line and sustainability: A literature review. Bus. Manag. Stud. 2015, 1, 6-10. [CrossRef] 
42. Rezai, S.H.; Allard, F.; Abelé, C.; Doya, M. Evaluating external thermal insulation composite systems (ETICS) regarding the building's global performance. Energy Procedia 2015, 78, 1562-1567. [CrossRef]

43. Cirami, S.; Evola, G.; Gagliano, A.; Margani, G. Thermal and economic analysis of renovation strategies for a historic building in mediterranean area. Buildings 2017, 7, 60. [CrossRef]

44. Sulakatko, V. Modelling the technical-economic relevance of the ETICS construction process. Buildings 2018, 8, 155. [CrossRef]

45. Biolek, V.; Hanák, T. LCC estimation model: A construction material perspective. Buildings 2019, 9, 182. [CrossRef]

46. Sulakatko, V.; Lill, I. The economic relevance of on-site construction activities with the External Thermal Insulation Composite System (ETICS). Int. J. Strateg. Prop. Manag. 2019, 23, 213-226. [CrossRef]

47. Meschede, $\mathrm{C}$. The sustainable development goals in scientific literature: A bibliometric overview at the meta-level. Sustainability 2020, 12, 4461. [CrossRef]

48. Rozporządzeniu Ministra Infrastruktury i Budownictwa z Dnia 17 Listopada 2016 r. w Sprawie Sposobu Deklarowania Właściwości Użytkowych Wyrobów Budowlanych Oraz Sposobu Znakowania ich Znakiem Budowlanym (Dz. U. poz. 1966 oraz z 2018 r. poz. 1233). Available online: http://isap.sejm.gov.pl/isap.nsf/ download.xsp/WDU20160001966/O/D20161966.pdf (accessed on 27 July 2020).

49. Building Research Institute (ITB); Institute of Ceramics and Building Materials (ICiMB); Institute of Mechanized Construction and Rock Mining (IMBiGS). Warunki Oceny Właściwości Użytkowych Wyrobu Budowlanego WO-KOT/04/02-Złożone Zestawy Izolacji Cieplnej z Wyprawami Tynkarskimi (ETICS) z Zastosowaniem Wyrobów ze Styropianu, 1st ed.; Building Research Institute (ITB): Warsaw, Poland, 2018.

50. Building Research Institute (ITB); Institute of Ceramics and Building Materials (ICiMB); Institute of Mechanized Construction and Rock Mining (IMBiGS). Warunki Oceny Właściwości Użytkowych Wyrobu Budowlanego WO-KOT/04/01-Złożone Zestawy Izolacji Cieplnej z Wyprawami Tynkarskimi (ETICS) z Zastosowaniem Wyrobów z Wetny Mineralnej, 1st ed.; Building Research Institute (ITB): Warsaw, Poland, 2018.

51. Building Research Institute (ITB). National Technical Approval ITB-AT-9090/2016 Zestaw Wyrobów do Wykonywania Ociepleń Ścian Zewnętrznych Budynków Systemem Atlas ETICS; Building Research Institute (ITB): Warsaw, Poland, 2016.

52. Building Research Institute (ITB). National Technical Approval ITB-AT15-2930/2016 Zestaw Wyrobów do Wykonywania Ociepleń Ścian Zewnętrznych Budynków Systemem Atlas ROKER; Building Research Institute (ITB): Warsaw, Poland, 2016.

53. Atlas. Environmental Product Declaration. Atlas ETICS External Thermal Insulation Composite System with Expanded Polystyrene Boards (EPS), Certificate No 078/2019; Atlas: Warsaw, Poland, 2019.

54. Atlas. Environmental Product Declaration. Atlas ETICS External Thermal Insulation Composite System with Mineral Wool Boards (MW), Certificate No 080/2019; Atlas: Warsaw, Poland, 2019.

55. European Committee for Standardization (CEN). EN 15804:2012+A2:2019 Sustainability of Construction Works-Environmental Product Declarations-Core Rules for the Product Category of Construction Products; European Committee for Standardization (CEN): Brussels, Belgium, 2019.

56. International Organization for Standardization (ISO). ISO 14025:2006 Environmental Labels and Declarations-Type III Environmental Declarations_Principles and Procedures; International Organization for Standardization (ISO): Geneva, Switzerland, 2006.

57. Albrecht, W.; Schwitalla, C. Rückbau, Recycling und Verwertung von WDVS: Möglichkeiten der Wiederverwertung von Bestandteilen des WDVS nach dessen Rückbau durch Zuführung in den Produktionskreislauf der Dämmstoffe bzw. Downcycling in die Produktion minderwertiger Güter bis hin zur energetischen Verwertung; Fraunhofer IRB Verlag: Stuttgart, Germany, 2015.

58. Eurostat. The statistical office of the European Union. NACE Rev. 2 Statistical Classification of Economic Activities in the European Community; Publications Office of the European Union: Luxembourg, 2020.

59. Muntean, M.; Guizzardi, D.; Schaaf, E.; Crippa, M.; Solazzo, E.; Olivier, J.G.J.; Vignati, E. Fossil CO2 Emissions of All World Countries-2018 Report; European Commission, EU Science Hub: Luxembourg, 2018.

60. European Environment Agency (EEA). The European Environment-State and Outlook 2020. Knowledge for the Transition to a Sustainable Europe; Publications Office of the European Union: Luxembourg, 2019; ISBN 9789294800909.

61. European Committee for Standardization (CEN). EN 197-1:2012 Cement Part 1: Composition, Specifications and Conformity Criteria for Common Cements; European Committee for Standardization (CEN): Brussels, Belgium, 2012. 
62. Stowarzyszenie Producentów Cementu. Environmental Product Declaration, Cements CEM I, CEM II, CEM III, CEM IV, CEM V Produced in Poland, Certificate No 116/2020; Stowarzyszenie Producentów Cementu: Cracow, Poland, 2020.

63. Palumbo, E.; Soust-Verdaguer, B.; Llatas, C.; Traverso, M. How to obtain accurate environmental impacts at early design stages in BIM when using environmental product declaration. A method to support decision-making. Sustainability 2020, 12, 6927. [CrossRef]

64. Czarnecki, L.; Kaproń, M. Sustainable construction as a research area. Int. J. Soc. Mater. Eng. Resour. 2010, 17, 99-106. [CrossRef]

65. Czarnecki, L.; Van Gemert, D. Innovation in construction materials engineering versus sustainable development. Bull. Pol. Acad. Sci. Tech. 2017, 65, 765-771. [CrossRef]

Publisher's Note: MDPI stays neutral with regard to jurisdictional claims in published maps and institutional affiliations.

(C) 2020 by the authors. Licensee MDPI, Basel, Switzerland. This article is an open access article distributed under the terms and conditions of the Creative Commons Attribution (CC BY) license (http://creativecommons.org/licenses/by/4.0/). 